\title{
5 and 7 Year Old Childrenwith No English Background RespondToward Parents' Stimulus Using the Comprehensible Inputs on Direct English Daily Conversations at Home
}

\author{
Setia Rini \\ English Department of Educational Faculty \\ State Islamic Studies Institute (STAIN) Salatiga \\ Jl. Tentara Pelajar no. 2 Salatiga, Central Java, Indonesia
}

\begin{abstract}
This paper seeks to explorehow the comprehensible inputs are given by mother responded by the children who have no English background and what are the discourse features which aid children's comprehension and ability to maintain the conversation. This study is conducted in the writer's home with her sons in order to apply the comprehensible inputs. The results shows that the children ages 5 and 7 years old who have no English background are able to give the responses unless the questions or the stimulus given must be followed by the non verbal language such as gesture and the body movements. In this case, the results can be varied. From the stimulus using the comprehensible inputs, the children are also giving different responses. It can be in the form of non-verbal language such as nodding or by repeating the last word said by their mother. It is suggested that parents should give encouragement to the children and help them in acquiring the second language at home.
\end{abstract}

Keywords: Parents' stimulus, Comprehensible inputs, daily conversation, with noEnglish background.

\section{Abstrak}

Studi ini berusaha untuk mengeksplorasi bagaimana input yang dapat dipahami, yang diberikan oleh ibu, direspon oleh anak yang tidak memiliki latar belakang bahasa Inggris dan apa saja fitur diskursus yang membantu pemahaman anak dan kemampuan untuk melakukan percakapan . Penelitian ini dilakukan di rumah penulis terhadap putranya dalam menerapkan input yang dapat dipahami . Hasil menunjukkan bahwa anak-anak berusia usia 5 dan 7 tahun yang tidak memiliki latar belakang bahasa Inggris mampu memberikan tanggapan dengan catatan bahwa pertanyaan atau stimulus yang

REGISTER, VOL. 1, N0. 1, 2008 
diberikan harus diikuti dengan bahasa non verbal seperti sikap dan gerakan tubuh. Dalam hal ini, hasilnya dapat bervariasi . Dari stimulus yang menggunakan input yang dapat dipahami, anak juga memberikan respon yang berbeda. Hal ini dapat dalam bentuk bahasa non -verbal seperti mengangguk atau dengan mengulang kata terakhir yang dikatakan oleh ibu mereka . Berdasarkan temuan tersebut, orang tua disarankan untuk memberikan dorongan kepada anak dan membantu mereka dalam perolehan bahasa kedua di rumah.

Kata kunci: Stimulus Orangtua, Input yang Dapat Dipahami, Percakapan Sehari-Hari, Tidak Memiliki Latar Belakang Bahasa Inggris

\section{Introduction}

Communication in English has now become a new trend in the modern families. It can be a tool to improve the social strata among them beside make their children fluent in speaking English. The way the children give responses to their parents' stimulus will be derived from the examples

given and from the process of imitation then the children try to produce the responses as well as they can. Both parents play an important role in their child's language development. If the mother spends more time with the children than the father, the language she speaks to the children will probably have more of an impact than the language the father speaks to the children. However, this does not mean that the father's language will not or cannot be acquired by the children. If the father makes an effort to spend quality language time with the children (reading stories, playing games, engaging in active conversation with the children), the children can and will learn the language he uses with them.

The children of those ages will only give simple responses because they do not get the intensive course on the subject in their formal education. As we know that in the kindergarten, they do not get the real English subject,

REGISTER, VOL. 1, N0. 1, 2008 
while in the elementary school, especially in Salatiga, this subject will be taught at the fourth level and only as the local capacity.

Children who have never learned the second language or the target language will try to give very simple responses such as saying yes or no or even just nodding. I try to apply this to my two sons as the object of the study. Both of them always try to give many different responses toward my questions and statements as the comprehensible inputs in English. The most important thing to me to do is how they can understand English as the means of communication in everyday life in their home. Children have the capacity to develop new language more naturally than do adults do. Children, who learn more than one language before adolescence, will acquire those languages with more ease and "native-like" ability than they would try to study those languages as adults.

In this case, the point is that both of my two sons have never been taught English by anybody. Therefore, the stimulus given must be followed by non-verbal aspects of communications or the body language and the facial expressions. I used auxiliary sequences and auxiliary-initial clauses in everyday, spontaneous speech, such as young children are routinely exposed to. These types of communication will become an effort to force the children to acquire the target language as well.

Acquiring a second language could be a lifelong learning process for some, and still, learners may never fully become native-like in the second language. Children, however, by around the age of 5-8, have more or less mastered the first language, with the exception of vocabulary and a few grammatical structures. The children's task therefore simply understands the input given by their parent. As also stated by Krassen (2000) that language can be acquired outside the target language environment, even without formal instruction, providing that learner are exposed to the comprehensible inputs.

REGISTER, VOL. 1, N0. 1, 2008 
The purpose of this study is to investigate how the comprehensible inputs given by mother are responded by the children who have no English background and to investigate what the discourse features, which aid children's comprehension and ability to maintain the conversation. The limitation of the study in this paper, I just analyze how to deliver the appropriate type of questions as the inputs given to 5-7 years old children who have no English background and the way to respond it.

\section{Second language acquisition}

How children acquire native language (L1) and the relevance of this to foreign language (L2) learning has long been debated. Although evidence for L2 learning ability declining with age is controversial, a common notion is that children learn L2s easily, whilst older learners rarely achieve fluency. This assumption stems from 'critical period' (CP) ideas.

A CP was popularized by Eric Lenneberg in 1967 for L1 acquisition, but considerable interest now surrounds age effects on second language acquisition (SLA). At the level of child second language acquisition, suchinteraction has been studied primarily as language-in-play,with the focus on learner output, but research on caretakerlanguage and foreigner talk has also led to studies of whether,and how, children simplify, repeat, and expand utterances asthey speak with less proficient interlocutors.

\section{Types of questions}

In order stimulating or reinforcing my children's language production in the second language, though my children have no English background, mother as the stimulant or the reinforcer in the process or producing the second language try to find the most appropriate questions, which make them as the comprehensible inputs. Therefore, the process of the interactions will

REGISTER, VOL. 1, N0. 1, 2008 
be in the natural situation where there are no disturbances and barriers in the second language acquisition.

There are five types of questions can be asked to children aged 5-8 years who have no English backgrounds. (Hatch: 1978:419) categorizes them into;(1) Display Questioning as the type of questioning used by the teacher in the classroom; (2) Repeated questions as all occurrences where the initial questions were repeated verbatim to the same listener; (3) Modified questions as questions which failed to produce an answer and which the questioner repeated in modified forms;(4) Initial questions as questions that the native speakers directed to language learners, either singly or as a group, includes repeated or rephrased questions addressed to different listeners. (5) Referential questions as questions occurred mostly in non-classroom settings. This type of questions can also be classified into open-ended questions; questions requiring provision of information rather than question referred.

\section{Non-verbal aspects of communications}

In communicating English with non-native children, the non-verbal aspects of communication play a highly important and essential role in foreign language acquisition among children and mother. As we know that mother speaks with the vocal organs but mother and children converse with the entire bodies. Conversations which include the process of questioning or giving the comprehensible input and answering or responding the input given, consist of much more than a simple interchange of spoken words.

Non-verbal communication has mainly been distinguished from verbal communication. Lorscher (1980) quoting Lyons,s (1977) description on non verbal communication which are including gestures, mimicry, proxemic behavior, speech pauses and pitch.

REGISTER, VOL. 1, N0. 1, 2008 
Then there are ten phenomena constitute the non-verbal communication, such as bodily contact, proximity, posture, physical appearance, facial and gestural movements, direction of gaze, and timing of speech, emotional tone of speech, speech errors and accent.

There are seven non verbal phenomena as described by Knapp (1977) taken from the Lorscher (2002), they are body motion or kinesic behavior, physical characteristic, touching behavior, paralanguage, proxemics, artifacts, environmental factors. By noting the description of non-verbal phenomena above, so nodding becomes the facial and gestural movements. The Indonesian children who have no English background will respond in different way toward the comprehensible input given.

This research is qualitative approach to get a clear description of the interaction between mother and children with focus on two type of questions, referential questions with the reason that such questions are usually occurred in non - classroom setting, which means that the questions are occurred at home during the daily activities and the display questions.

The subject of the study is two of the researcher's children aged 5 and 7 years old who have no English background. The location of data collection takes place in the researcher's house. The data are collected in the form of recorded data and used as the data base in order to identify which type of mother's questions and statements are considered to create the comprehensible inputs on the children. The data are in the form of speech and action. The conversations occur spontaneously without any specific guidelines for mother and children for choosing the topics. The aim of this study is investigating the appropriate type of questioning to children aged 5-8 years old who has no English background using the comprehensible input and the way to give respond as the language production, so the unit of analysis of the study is in the form children's utterances as the responses of the inputs

REGISTER, VOL. 1, N0. 1, 2008 
and mother's utterances as the stimulus for the comprehensible inputs. In techniques of data collection, I used the direct questioning with both of my sons in English about the daily topics, the direct questioning lasted for approximately ten minutes, and a small tape recorder was placed near the parent in order o get the natural data.

Technique of data analysis, there are some steps in doing the analysis are first through transcribing or recording the interaction I made with both of my sons. This transcription becomes a subject of analysis that makes the analysis easier to conduct. In the form of written material, the interaction among my children and I involving question and answer can be easily notified. In transcribing the data, I presented the data as follows: full stops (.), comma (,), question mark (?), exclamation mark (!), turn numbers $(1,2,3 \ldots)$. The participants are coded; mother (M), children $1(\mathrm{C} 1)$ and children $2(\mathrm{C} 2)$. The utterances were transcribed as they were said without any correction to the grammatical error. Second is selecting. After the transcription was done, I selected the mother's questions and statements as the comprehensible inputs and rewrote them on a separate sheet of paper. This was done to make the analysis easier. The third is categorizing the turns; questions and statements based on the questions types (display questions and referential questions). I also recorded my children's responses to those questions and statements, so that it would be easier whether mother's inputs stimulate answers from children. Then I categorized children's responses in three categories; no

response (including non-verbal response), short answer (for one or two words answer) and long answer (for more than two words answer).

\section{Discussion}

The followings are my findings and discussions that show the mother and children interactions conducted every day in a week, which are then 
transcribed. The two children are both male whose respond will be analyzed through the comprehensible input given by their mother as the researcher.

For the purpose of analysis, then the data taken from the tape recorder first is categorized into turns. The term turn denotes an utterance or uninterrupted sequence of utterances, produced by a single speaker (Sack, Schegloff and Jefferson: 1974). The two categories of turns are questions and statements.

Table 1

Distribution of Turns

\begin{tabular}{|l|l|l|l|l|}
\hline Speaker & Questions & $\begin{array}{l}\text { Statement } \\
\text { s }\end{array}$ & Total & $\begin{array}{l}\text { Gesture } \\
\text { Movements }\end{array}$ \\
\hline Mother & 9 & 11 & 20 & 10 \\
\hline & $45 \%$ & $55 \%$ & $100 \%$ & $100 \%$ \\
\hline Zulfan & 0 & 5 & 5 & 0 \\
\hline & $0 \%$ & $100 \%$ & $100 \%$ & $0 \%$ \\
\hline Yoga & 2 & 8 & 10 & 0 \\
\hline & $20 \%$ & $80 \%$ & $100 \%$ & $0 \%$ \\
\hline
\end{tabular}

From the tabulation above, the total number (45\%) for questions and $(55 \%)$ for statements, mother dominates the conversation as the process of giving the comprehensible inputs which are followed by the non verbal language, in this case is called gesture movements, because while giving the inputs, mother inserted the gesture movements to make children understand what their mother said as the process of comprehending the inputs. The children do not make non-verbal language while responding the comprehensible input given by the mother, and they tend to respond directly through nodding or answering yes or no toward the inputs.

REGISTER, VOL. 1, N0. 1, 2008 
Table 2

Types of Questions

\begin{tabular}{|l|l|l|l|}
\hline Speaker & Display & Referential & Total \\
\hline Mother & 0 & 20 & 20 \\
\hline & $0 \%$ & $100 \%$ & $100 \%$ \\
\hline
\end{tabular}

The questions asked by mother were referential questions. These interactions do not take place in a classroom and the conversations were about various matters unrelated to structured classroom dialogues. This result supports the findings of Long and Sato (1983) who found their analysis of six ESL lessons to adults in USA, that the dominant type of questioning used by teachers in the classroom was display questioning, while referential questions occurred mostly in non - classroom settings.

Mother's questions, which belong to referential questions mostly, are dominated with questions, (100\%) that are questions requiring only yes / no answers. Mother tried to focus the questions, which are related to the daily topics, and which are spontaneously asked based on the situation where the children are:

In the morning while preparing their self to go to school:

Mother: "Hi, good morning dik Yoga"

Yoga : "Good morning, ibu"

Mother: "How are you dik Yoga?"

Yoga : "How are you dik Yoga?"

Mother :'Dik Yoga, have you got breakfast? Eat?" (Mother moves her hand to her mouth)

Yoga : "Belum makan"

Mother : "Yesterday you've got a broken arm, right?" (Mother puts her right hand into her left hand)

Yoga : "Broken"

Mother :'Dik, the cat is eating gereh, right?"(Mother pointed her finger to the cat in front of them which is still eating the bone of the fried salted fish)

Yoga : (nodding)

REGISTER, VOL. 1, N0. 1, 2008 
Mother :'The cat's mother is coming ya dik."(Mother pointed the cat's mother which is coming to her kitten which is still having the bone of fried salted fish)

Yoga :'( nodding)

After going back from school:

Mother :"Welcome home, dik Yoga.....You are dropped by Bu Sri, right?"

Yoga :"( Smile and nodding)

Mother :'Do you feel happy? You get home by being dropped by Sri and Bentar?"

Yoga :" Ojo ngomong ngono. Buk kolak!"

Mother :"Oh, you want me to make you kolak, right?

Yoga :"Yes".

They were in their spare time in the afternoon:

Mother : "Mas Zulfan, do you like watching the siluman sinetron in Indosiar?"

Zulfan : "Yes."

Mother : "Yoga, you like watching the CD series of Ultraman, right?"

Yoga :"Yes."

Mother : "Mas Zulfan, will you have a sleep right now?"

Zulfan :"No."

In the evening:

Mother :" Mas Zulfan, you have already finished taking a bath, right?"(Mother moves her hand into the body and acted like

Zulfan :"Yes!" the one who are taking a bath)

Mother :'Mas Zulfan, do you feel fresh?"(Mother acted by folding both of her arms)

Zulfan :"Yes, sudah mandi badan segar."

Mother :'Mas Zulfan, you choose to wear that pajama, don't you feel hot?"(Mother acted that she felt hot by clapping her front shirt)

Zulfan :'No."

Yoga :'Mamah, bukakan bungkusan wafer ini, mah."

REGISTER, VOL. 1, N0. 1, 2008 
Mother :"Okey, take that basket over there, please." (Mother pointed her hand to the position of the basket)

Yoga :'Basket? Ini?."

Mother :'Yes. Inside the basket, there is a scissor. (Mother showed one of the children the symbol of a scissor using her right hand.) Yes, good. You are a good boy. (Mother shows her right thumb up). Thank you."

Yoga :'Thank you."

Mother :'Dik Yoga, you were crying this morning, hoa, hoa, right? (Mother put one of her right hand neat her right eyes)

Yoga : "Yes."

The unit analysis of this study is mother's utterances in the form of comprehensible inputs and children's utterances as the direct responses toward the inputs given.

\section{Mother: "Hi, good morning dik Yoga" Yoga : "Good morning, ibuk"}

Mother delivered the inputs in the form of greeting. The situation took place in the morning. One the children responded it by saying "good morning ibuk". Actually the child has been introduced the way to respond such greeting by his mother, as the researcher, but he still used the word ibuk not mother, because he imitated her mother's way of calling his name, dik Yoga.

\section{Mother: "How are you dik Yoga?"}

Yoga : "How are you dik Yoga?"

In this case, mother still delivered the inputs in the form of greeting. The situation took place in the morning. One the children responded it by saying "how are you ibuk". Actually the child has been introduced the way to respond such greeting by his mother, as the researcher, but he still used the word ibuk not mother, because he imitated her mother's way of calling his name, dik Yoga.

REGISTER, VOL. 1, N0. 1, 2008 
3. Mother:"Dik Yoga, have you got breakfast? Eat?" (Mother moves her hand to her mouth)

Yoga : "Belum makan"

The way mother delivered the input was also followed by the non-verbal language in the form of body motion or kinesic behavior. She showed her son the way one eats. The child then understood toward the inputs so he replied "belum makan". It means that he understands what the mother said, and he replied it in his first language. The situation of that conversation took place when mother as the researcher were feeding him before going to school.

4. Mother: "Yesterday you've got a broken arm, right? Broken" (Mother puts her right hand into her left hand) Yoga : "Broken"

In this case, mother tried to move to other topic dealing with his current condition. The child has a broken arm due to a small accident that took place at home in the morning, while everybody was preparing everything to go to school and to the office. He fell down from a motorcycle and he got his left arm broken. Then mother asked him that yesterday he got a broken arm. The way the mother gave the input was also followed by non-verbal language in the form of body motion, she held her left arm and moved it up and down in the similar way the one has a broken arm. Then the respond given by the child is by saying "broken". In this case, he actually understood and tried to imitate what his mother said in the last word, because she tried to make him understand to what she said and still showed him the moving of her left arm.

5. Mother:"Dik, the cat is eating gereh, right?"(Mother pointed her finger to the cat in front of them which is still eating the bone of the fried salted fish)

Yoga : (nodding)

REGISTER, VOL. 1, N0. 1, 2008 
In this case, mother was feeding him for breakfast before going to school and they had "gereh" or fried salted fish. While they had it, the cat was coming toward them and mother gave the bone of the fried salted fish to the cat. Then she said that the cat is eating gereh. She used the word 'gereh' in order to make the child understand what the cat is doing. The child gave that respond by nodding as the form of non-verbal language. It means that he understood what the input given by his mother.

6. Mother:"The cat's mother is coming ya dik."(Mother pointed the cat's mother which is coming to her kitten which is still having the bone of fried salted fish) Yoga :"(nodding)

Still, mother fed her second son. While feeding her son, the mother of the cat is coming toward them. Therefore, mother said to her son that the mother of the cat is coming and in this case, mother pointed her finger to the cat's mother that is coming to her kitten that is still having the bone of fried salted fish. Then the boy responded it by nodding. It means that he could understand the input given by the mother in the target language. In the morning, her second son, Zulfan who are 7 years old, has gone to school with his father early in the morning at around 6.30 a.m. Zulfan is still in first year of Elementary School and he returns home at 10.45 a.m. The comprehensible inputs are given to her second son, Yoga, who is 5 years old. He is still in the first year of the kindergarten. He goes to school at 7.30 a.m. and he goes home at 10.00 a.m.

7. Mother:"Welcome home, dik Yoga.....You are dropped by Bu Sri, right?"'(Mother open her to hands acted that she welcomes someone) Yoga :"( Smile and nodding)

REGISTER, VOL. 1, N0. 1, 2008 
In this case, her son went home by being dropped by his teacher, named Sri. Therefore, mother welcomed him by giving the input in the target language. She acted as if she welcomes someone. She inserted the word 'Bu Sri' not your teacher, means that her son will easily identify what she already said to her son. Yoga understood toward his mother's saying, then he gave responds in the form of non-verbal language, in this case, he showed his facial expression through smiling and body motion in this case nodding.

8. Mother:"Do you feel happy? You get home by being dropped by Bu Sri and Bentar?"

Yoga :" Ojo ngomong ngono. Buk kolak!"

In this situation, the boy seems uncomfortable, because he has just already got home, perhaps he felt so tired. His mother kept on asking him as the process of giving the comprehensible inputs, by asking the question in the same context, that he got home by being dropped by his teacher, Bu Sri and his friend, Bentar, Bu Sri's nephew. So he would probably feel happy. Therefore, he replied surprisingly. He said," Ojo ngomong ngono". It means that he forbade his mother not to speak in the target language. Then he continued by saying "Bu Kolak". He asked for a glass of 'kolak' a kind of beverages that is made from boiled water that is mixed with the essence of coconut, sugar, and bananas. It is because he felt thirsty.

9. Mother:"Oh, you want me to make you kolak pisang, right?" (Mother tried to explain him in the target language and pointing her finger into his body and her body) Yoga :"Yes".

In this case mother tried to make sure that he wanted her mother to make him kolak pisang, by inserting the words' kolak pisang' and she explained it in the target language and tried also to use a body motion as the non verbal

REGISTER, VOL. 1, N0. 1, 2008 
language such as pointing her finger to her body and his body. Then he replied by saying 'yes' showing that he understood to what his mother said.

10. Mother: "Mas Zulfan, do you like watching the siluman sinetron in Indosiar?" (Mother pointed her finger to the television) Zulfan : "Yes."

In the different context of time, this conversation took place in the spare time after going back from school. Mother tried to give the input to her first son, Zulfan who was still watching the siluman sinetron program in television. The word 'sinetron' is derived from the word Electronic Cinema that is broadcasted in the form of series. The word 'siluman' means the movie about the Javanese myths creature. Zulfan was able to reply the input given by his mother directly by referring to the word 'siluman sinetron in Indosiar'. The word Indosiar has also familiar to him, because it is one of the television channels in Indonesia. The way the mother delivered the question was by calling his name, 'Mas Zulfan', it means to get his attention, not his younger brother's attention and by pointing her finger to the television.
1. $\quad$ : "Dother Yoga, you like watching Yoga :'Yes."

In this case, mother tried to get her second son's attention by calling his name, dik Yoga. Then she tried to ask about one of his CD robotic hero's collections entitled 'Ultraman Cosmos'. Yoga replied 'yes' because he got the word 'CD' and 'Ultraman' that he has it at his collections and he was familiar with those words.

2.

Mother : "Mas Zulfan, will you have a sleep right now?"(Mother put her hands close to her left cheek and she closed her eyes Zulfan showing the activity of sleeping) :"No."

REGISTER, VOL. 1, N0. 1, 2008 
In this case mother gave the input followed by the non verbal language, such as body motion through putting her hands close to her left cheek and she closed her eyes showing the activity of sleeping, so her first son would understand it easily and finally he replied 'no', because he didn't want to sleep in the time they were speaking.

3.

Mother :" Mas Zulfan, you have already finished taking a bath right?"(Mother moves her hand into the body and acted like the one who are taking a bath)

Zulfan :"Yes!"

In this case, the situation took place in the evening when her sons had already finished taking a bath. Mother got her first son's attention by calling 'Mas Zulfan', so that the one who would be responsible to give the respond is he. In focusing on the action of taking a bath, then mother acted as the one who is still taking a bath, she used her non-verbal language in the form of body motion. The child can respond again directly by saying 'yes'.

4.

Mother :"Mas Zulfan, do you feel fresh?"'(Mother acted by folding both of her arms)

Zulfan : :Yes, sudah mandi badan segar."

In this case, mother gave input still dealing with the activity of taking a bath. She asked him by also getting his attention first then asked his feeling after taking a bath followed by the non verbal language again, she showed him the way one performed the action of feeling fresh by folding her both arms. Then her first son replied 'yes' because he understood the input given and continue to say in his first language 'sudah mandi badan segar' which means that after taking a bath then he feels fresh on his body.

REGISTER, VOL. 1, N0. 1, 2008 
In this case, also, the situation is still dealing the activity after taking a bath. He put on his pajamas in the hot weather. That is why mother asked him about the feeling of having the pajamas. So the context is still known by the child. She delivered the input followed by the non verbal language in this case is body motion, she acted that she felt hot by clapping her front shirt back and forth. The boy then replied by saying 'no', because he understood what the input given by his mother and he actually would wear that kind of shirt, so he didn't care to the weather whether it was cold or hot.

\section{Yoga :"Mamah, bukakan bungkusan wafer ini, mah." Mother :"Okey, take that basket over there, please." (Mother pointed her hand to the position of the basket) \\ Yoga :"Basket? Ini?." \\ Mother :"Yes. Inside the basket, there is a scissor. (Mother showed one of the children the symbol of a scissor using her right hand.) Yes, good. You are a good boy. (Mother shows her right thumb up). Thank you." \\ Yoga :"Thankyou."}

By the time, the conversation between the first son and the mother took place, and then the second son was entering the room by handling a pack of wafer. The boy then asked her to open the pack of wafer, but still in his first language. Then mother tried to give her order as the input in the target language. She said that the boy should take the basket as the place of the scissor; she pointed her finger to the position of the basket. Then he replied by imitating what his mother said, "Basket?", "ini?" and he come forward to 
the position of the basket. Then mother replied again in the target language, by saying 'yes'. She explained him that there is a scissor inside the basket, mother followed her word with the body motion as the non verbal language, and she moved her right hand to show him what a scissor is like. Then she said 'good' because the boy could find the scissor. She continued to say 'you are good boy' and showed her son her right thumb up. Then she said 'thank you', and finally the boy can reply in the right way, thank you.

7. Mother :'Dik Yoga, you were crying this morning, hoa, hoa, right? (Mother put one of her right hand near her right eyes) Yoga : "Yes."

In this case, mother tried to give the input to her second son to remind him that this morning he cried so hard. She showed her son the way the one cried by putting her fingers close to her eyes, and said 'hoa,hoa. The child understood to what her mother said, so he replied 'yes'.

From the classification of the interaction among mother and the children as the process of giving the comprehensible inputs and the children's responds were found that mostly mother delivered the questions by getting the attention one of the children who would be asked through calling his name. It is expected that one of them will answer the questions as the input given by the mother. Mother mostly inserting the non verbal language while delivering the comprehensible inputs in the form of statements and referential questions by showing the body language or gesture movements to the children such as acting in the similar way the children do their activities.

The way both children give, the responds are varied. It can be seen that for some inputs are responded by using three categories; no response (including non-verbal response), in this case they nod, short answer (for one or two words answer); in this case they say yes or no, and long answer (for

REGISTER, VOL. 1, N0. 1, 2008 
more than two words answer); in this case they answer the questions by using their own first language.

\section{Conclusion}

After analyzing the data above, I can conclude that the children who have no English background at all are able to be stimulated to the English conversation using English, which are accompanied, by some body language, gesture, or non-verbal language. This can lead them to the more intensive communication without forcing them to produce complex responses. The most important thing is that they are able to comprehend the inputs, which are given in the target language as the process of acquiring the second or the foreign language. By knowing the importance of English as the international means of communications, most of the English teachers and those who are able to speak English can prepare their children to understand English in the daily lives through stimulating them with the target language which are accompanied by the body language or non verbal language as the process of giving the comprehensible inputs, so that the children will be able to process the inputs easily.

\section{References}

Harley, B. 1986. Age in Second Language Acquisition. Clevedon: Multilingual Matters.

Hatch, E.M. 1978. Discourse Analysis and Second Language Acquisition. In hatch, E.M. Second Language Acquistion: A Book of Readings. 401435. Rowley, Mass.: Newbury House

Krashen, S.D. 1975. The Critical Period for Language Acquisition and its Possible Bases. In D. Aaronson and R.W. Rieber (eds), Developmental Psycholinguistics and Communication Disorders. New York: New York Academy of Sciences.

REGISTER, VOL. 1, N0. 1, 2008 
Krashen, S. 2000. What Does It Take to Acquire Language?, ESL magazine V3 n3:p22-23.

Long, M and Sato,C.J. 1983. Classroom Foreigner Talk Discourse: forms and Functions of Teacher's Questions. In H.Seliger \&M.Long (Ed.) Classroom Oriented Research in Second Language Acquisition 26885. Rowley, Massachusetts: Newbury House Publishers.

Piaget, J. 1926. The Language and Thought of the Child. Translated by E. Claperede. London: Kegan Paul

Flanigan, Beverly Olson. Peer Tutoring and Second Language Acquisition in the Elementary School.Retrieved from http://applij.oxfordjournal.org/misc/term.dtl

Lorscher, Wolfgang. Non verbal Aspects of Teacher- Pupil Communication in the Foreign Language Classroom. lorscher@rz.uni.Leipzig.

REGISTER, VOL. 1, N0. 1, 2008 